\title{
BMJ Open Use of infectious disease surveillance reports to monitor the Zika virus epidemic in Latin America and the Caribbean from 2015 to 2017: strengths and deficiencies
}

\author{
Joan K Morris (D) , ${ }^{1}$ Helen Dolk, ${ }^{2}$ Pablo Durán, ${ }^{3}$ leda Maria Orioli ${ }^{4,5}$
}

To cite: Morris JK, Dolk H, Durán $\mathrm{P}$, et al. Use of infectious disease surveillance reports to monitor the Zika virus epidemic in Latin America and the Caribbean from 2015 to 2017: strengths and deficiencies. BMJ Open 2020;10:e042869. doi:10.1136/ bmjopen-2020-042869

- Prepublication history for this paper is available online. To view these files, please visit the journal online (http://dx.doi. org/10.1136/bmjopen-2020042869).

Received 16 July 2020 Revised 17 November 2020 Accepted 25 November 2020

Check for updates

(C) Author(s) (or their employer(s)) 2020. Re-use permitted under CC BY-NC. No commercial re-use. See rights and permissions. Published by BMJ.

For numbered affiliations see end of article.

Correspondence to Professor Joan K Morris; jmorris@sgul.ac.uk

\section{ABSTRACT}

Objectives To summarise the occurrence of congenital Zika syndrome (CZS) in Latin America and the Caribbean from 2015 to 2017 using two outcome measures derived from infectious disease surveillance reports and to assess the completeness of these reports.

Design Surveillance study.

Setting Pan American Health Organization (PAHO)/WHO epidemiology reports on confirmed and suspected Zika virus infection and cases of CZS.

Participants Populations of 47 countries in the South and Central Americas, Mexico and the Caribbean.

Primary and secondary outcome measures The number of CZS cases per 1000 births (using 2016-2017 births as a denominator) and the number of CZS cases per 1000 births in women with Zika virus infection during pregnancy.

Results By 4 January 2018, 548623 suspected and 239063 confirmed Zika virus infections had been reported to PAHO/WHO from 47 countries. In 25 countries, over $80 \%$ of infections were reported as suspected. There were 3617 confirmed CZS cases in 25 countries; 2952 (82\%) had occurred in Brazil. The number of CZS cases per 1000 births varied considerably with Brazil and several Caribbean island communities (Puerto Rico, St Martin, Martinique, Guadeloupe and Grenada) having the highest CZS prevalence above 0.5 per 1000 births. Analysing the number of CZS cases per 1000 births in women infected with Zika virus during their pregnancy highlighted the inaccuracies of the data, with Venezuela likely to have had severe under-reporting of CZS.

Conclusions Expressing data on CZS in relation to total births, rather than as absolute numbers, better illustrates the burden of disease, providing that underreporting of CZS is not too severe. Data on infections in pregnant women enable potential under-reporting of CZS to be identified. Both measures are recommended for future PAHO/WHO publications. Evidence of severe under-reporting of Zika virus infections and CZS makes interpretation of the data and comparisons between countries challenging.

\section{INTRODUCTION}

In 2015 in North East Brazil, a sudden increase in cases of microcephaly were reported after
Strengths and limitations of this study

- A strength is that surveillance data from every country in Latin America and the Caribbean were analysed.

- A further strength is that the number of congenital Zika syndrome cases were population-weighted by the number of births, which is not regularly done in Pan American Health Organization/WHO reports, and which gives a better idea of the disease burden.

- A limitation is that the publicly available data do not include the numbers of people in a population who were tested (including the numbers of pregnant women), and the indication for testing, which would enhance the interpretation of the reported incidence of Zika virus.

the introduction of Zika virus into Brazil. ${ }^{1}$ Since then it has been established that Zika virus infection in the first trimester of pregnancy does increase the risk of the fetus having microcephaly. ${ }^{2}$ Several studies have subsequently characterised additional brain abnormalities associated with Zika virus infection during pregnancy and the diagnosis of congenital Zika syndrome (CZS) has been defined. $^{3-5}$ There is uncertainty about the risk of CZS given a woman is infected with Zika virus in the first trimester with one study reporting the risks of $\mathrm{CZS}^{3}$ and three studies reporting the risks of microcephaly. ${ }^{6-8}$ Microcephaly is not always present in CZS and therefore the prevalence of microcephaly in women with first trimester Zika virus infections will be lower than the prevalence of CZS. ${ }^{9}$ A study of women in America who were pregnant and had evidence of Zika virus infection during pregnancy (both symptomatic and asymptomatic) found that 60 per 1000 pregnancies were diagnosed with CZS. ${ }^{3}$ A case-control study comparing neonates in 
Recife Brazil with microcephaly with controls without estimated that the relative risk of microcephaly given Zika virus infection during pregnancy was 73.1. ${ }^{6}$ If the prevalence of microcephaly in women without Zika virus infections is as estimated by Orioli et al at 0.44 per $1000,{ }^{10}$ a relative risk of 73.1 is equivalent to an absolute risk of around 32 per 1000 births to women with Zika virus infections. ${ }^{3}$ Cauchemez et al retrospectively analysed the Zika virus outbreak in French Polynesia and estimated that the risk of microcephaly from infection in the first trimester was 9.5 per 1000 women infected in the first trimester. ${ }^{7}$ Brady et al used data from Brazil to estimate that 4 per 1000 pregnancies infected with Zika virus in the first two trimesters would result in a case of microcephaly. ${ }^{8}$ In summary, estimates of the risk of microcephaly or CZS given the mother was infected with Zika virus during pregnancy vary from 4 per 1000 (the lowest estimate for microcephaly) to up to 60 per 1000 births for CZS.

The aim of this study was to summarise the occurrence of CZS in Latin America and the Caribbean from 2015 to 2017 using the number of CZS cases per 1000 births and the number of CZS cases per 1000 births in women with Zika virus infection during pregnancy. These two measures can be derived from infectious disease surveillance reports and provide information about the burden of disease and the completeness of the surveillance reports.

\section{METHODS}

Since May 2015, Pan American Health Organization (PAHO)/WHO have reported data on the spread of the Zika virus in all countries in Latin America and the Caribbean. ${ }^{11}$ The weekly reports include the cumulative numbers of reported Zika virus cases (suspected and confirmed), the incidence rates per 1000 people, the numbers of deaths among Zika infection cases and the numbers of confirmed CZS cases.

Data were taken from the PAHO/WHO publications of cumulative cases available on the website (http://www. paho.org/data/index.php/en/?option=com_content\& view $=$ article\&id $=524 \&$ Itemid=) up until January 2018 (accessed 8 October 2020).

A series of reports published on 25 September 2017 from all countries and territories with autochthonous transmission of Zika virus in the Americas provided additional information on the number of pregnant women with suspected and confirmed Zika virus infections up until week 35 in 2017. These data were downloaded from the website: https://www.paho.org/hq/index.php? option=com_content\&view=article\&id=11603: countriesand-territories-with-autochthonous-transmission-of-zikavirus-in-the-americas-reported-in-2015-2017\&Itemid= 41696\&lang=en (accessed 3 January 2020). Several countries only reported pregnancies in 2016 and hance were likely to have excluded some infected pregnancies occurring in 2017.
Data from Canada, the USA and Bermuda were excluded-only countries in the South and Central Americas, Mexico and the Caribbean were analysed. Apart from in Brazil, no cases of CZS were reported in 2015-they were all reported in 2016 and 2017. Therefore, we calculated the CZS per 1000 births using the total number of births in 2016 and 2017. The numbers of live births occurring during 2016 and 2017 were obtained in each country from the United Nations Demographic Yearbook 2017. ${ }^{12}$ In the following countries, the numbers of births were only available for earlier years and the numbers occurring in 2016-2017 were estimated to be twice that in the most recent year of data available: Honduras (2012), Haiti (2013), Grenada (2014), Trinidad and Tobago (2015), El Salvador (2015) and Guyana (2015).

The PAHO/WHO case definitions for suspected and confirmed Zika cases and CZS that were communicated to the member states and were used to report cases within the International Sanitary Regulations are given at http://www.paho.org/hq/index.php?option=com content\&view=article\&id $=11117$ \&Itemid $=41532 \&$ lang $=$ en (accessed 22 May 2020).

\section{Statistical analysis}

The number of CZS cases per 1000 births was calculated to give a population-adjusted measure of the relative size of the CZS epidemic in each country, as well as a measure of the proportion of births affected relative to other perinatal problems.

Island communities have been reported to often experience much higher infection rates than larger mainland communities $^{13}$ and therefore it might be expected that the number of CZS cases per 1000 births would be higher on islands. To investigate this, a binomial regression model was fitted with each country as a random effect and island as a fixed effect.

Each country reported both suspected and confirmed Zika virus infections. Main analyses reported are based on both confirmed and suspected cases, but analyses including only confirmed cases were also performed and are compared where relevant.

The number of pregnant women who were infected with the Zika virus during their pregnancy was obtained from individual country reports on 25 September 2017 covering all reports up until week 35 of 2017. Some countries reported both suspected and confirmed cases separately, while other countries reported suspected and confirmed cases in total or either only suspected or confirmed cases. The total number of suspected and confirmed cases was analysed and if this was not available the number of cases reported was used regardless of whether they were suspected or confirmed. The number of CZS cases per 1000 women who were infected with the Zika virus during their pregnancy was calculated and will be referred to as CZS cases per infected pregnancies. This measure would be expected to be around 4-60 per 1000 pregnancies with differences highlighting possible reporting issues. 
Linear associations between variables were quantified using Spearman's rho rank correlation coefficients.

\section{RESULTS}

Table 1 shows that by the 4 January 2018, 548623 suspected Zika virus infections and 239063 confirmed Zika virus infections had been reported to $\mathrm{PAHO} / \mathrm{WHO}$. There were 3617 confirmed CZS cases, of which the largest numbers of cases were reported in Brazil (2952 cases; $82 \%$ ) and Colombia (248; 7\%).

Figure 1 compares the number of CZS cases per 1000 births with the incidence rate of Zika virus infections (confirmed and suspected). The two measures are linearly related (spearman's rho $=0.64, \mathrm{p}=0.008$ ) as is expected as a higher incidence of Zika virus would be expected to lead to a higher birth prevalence of CZS. However, there is much variation in the number of CZS cases per 1000 births not explained by the incidence of Zika virus in the population. The random effects model estimated that countries that are islands have $82 \%(95 \%$ CI 54\% to 116\%) higher rates of CZS per 1000 births than non-island communities. Haiti is the exception with only 1 CZS case reported out of over 3000 Zika virus infections, indicating under-reporting of CZS. French Guiana, Honduras, El Salvador, Nicaragua, Mexico and Argentina also have lower number of CZS cases per 1000 births than might be expected due to their reported incidence of Zika virus infections, also indicating under-reporting of CZS. The correlation between the birth prevalence and the incidence of Zika virus is weaker (spearman's rho $=0.48, \mathrm{p}=0.02$ ) if only confirmed Zika virus infections are analysed (data not shown). This can be partly explained by several countries having over $90 \%$ of their cases suspected rather than confirmed and three countries having no confirmed cases (Martinique, Haiti and Venezuela) indicating that in these countries Zika virus infections although they are suspected are often not confirmed. Another explanation could be differential reporting of CZS, which we know occurred with Brazil being more likely to diagnose CZS than other countries. Table 1 shows that four countries had over 6000 Zika virus infections and yet reported no cases of CZS (Venezuela, Jamaica, Peru and Curacao) suggesting potential underreporting of CZS in these countries.

Table 2 shows that 36025 pregnancies were reported to have been confirmed as having been infected with Zika virus, with $32 \%$ of these being in Brazil and 18\% in Colombia. A total of 71230 pregnant women were reported as having confirmed or suspected Zika virus infections (assuming that the number of suspected or confirmed cases is equal to the number of confirmed cases in countries only reporting confirmed cases); $37 \%$ in Brazil and 28\% in Colombia.

Figure 2 and table 2 present the number of CZS cases per 1000 women who were infected with Zika virus during their pregnancy for each country compared with the reported values from previous studies of between 4 and 60 CZS cases per 1000 pregnant women with Zika virus. ${ }^{3}$ 6-8 Many countries do have a prevalence close to these values. Slightly higher rates (such as in Brazil) may suggest more extensive reporting of CZS than of infected pregnancies, or the use of wider microcephaly definitions earlier in the epidemic. In Argentina, there were five cases of CZS reported and only five pregnant women were reported as being infected with Zika virus indicating that reporting only occurred when CZS was confirmed and therefore their rate of 1000 CZS per 1000 pregnancies is clearly incorrect (and not plotted in figure 2). Three other countries reported at least one case of CZS, but did not report any infected pregnancies (Guyana, Grenada and Suriname). Several countries such as French Guiana, Mexico and Nicaragua have much lower values indicating that cases of CZS were being under-reported. This can be explained for Nicaragua by the fact that they reported infected pregnancies only up until week 1 of 2017. Four countries in figure 2 reported $>200$ pregnant women having Zika virus infections (Venezuela (3463), Jamaica (712), Peru (279) and the Virgin Islands (USA) (286)) and yet reported no cases of CZS. The upper CI being around 1 suggests under-reporting of CZS in Venezuela, but the numbers of infected pregnancies are too small to be informative in the other countries. Haiti only reported infected pregnancies up until week 21 of 2016. Figure 2 indicated that Haiti might have under-reported CZS cases and therefore figure 2 indicates that they are also likely to have under-reported the number of infected pregnant women as the ratio of the two values is reasonable.

Figure 3 shows the number of pregnant women who were infected with Zika virus per 1000 births and compares this with the reported incidence of Zika virus in the population. The majority of countries were above the line of equality indicating that infections in pregnant women were more likely to be reported than infections in the rest of the population. This was likely to be due to pregnant women being more likely to be tested for Zika virus infection, since they are the high-risk segment of the population. The countries below the line of equality were perhaps under-reporting the numbers of pregnant women with Zika virus infection, particularly Haiti, Belize and Saint Vincent and the Grenadines who only reported infected pregnancies in 2016 not in 2017.

Zhang et l $^{14}$ used data from a study in Bahia in Brazil from October 2014 to February $2016^{15}$ and data from a study of the 2013 Zika virus outbreak in French Polynesia ${ }^{13}$ to develop a global stochastic epidemic model to analyse the spread of the Zika virus (ZIKV) in Latin America and the Caribbean. Table 3 compares their predictions with the reported figures. The agreement is reasonable for Brazil, Colombia and Puerto Rico, but much higher for Mexico, El Salvador, Honduras, Haiti and Venezuela. These later countries are all countries which our analysis has indicated have under-reporting of CZS cases. This provides further indication that the reporting to PAHO/ WHO is not sufficiently accurate to validate prediction models in some countries. 
Table 1 Zika virus infections and CZS cases reported to PAHO/WHO by countries in the South and Central Americas, Mexico and the Caribbean, 2016 -2017* and the estimated number of CZS cases per 1000 births to pregnant women with Zika virus

Zika virus infections†

CZS

\begin{tabular}{|c|c|c|c|c|c|c|c|c|c|c|}
\hline Country & Suspected & $\begin{array}{l}\text { Confirmed } \\
\text { (including } \\
\text { imported) }\end{array}$ & $\begin{array}{l}\% \\
\text { Suspected }\end{array}$ & $\begin{array}{l}\text { Total } \\
\text { suspected } \\
\text { and } \\
\text { confirmed }\end{array}$ & $\begin{array}{l}\begin{array}{l}\text { Incidence } \\
\text { of Zika virus } \\
\text { (suspected } \\
\text { and } \\
\text { confirmed) } \\
\text { per } 1000 \\
\text { people per } \\
\text { year }\end{array}\end{array}$ & $\begin{array}{l}\text { Incidence } \\
\text { of Zika virus } \\
\text { (confirmed) } \\
\text { per } 1000 \\
\text { people per } \\
\text { year }\end{array}$ & $\begin{array}{l}\text { CZS } \\
\text { cases }\end{array}$ & $\begin{array}{l}\text { CZS per } \\
1000 \text { births } \\
(2016 / 17)\end{array}$ & $\begin{array}{l}\text { Population } \\
\text { ('000) in } \\
2016 / 17\end{array}$ & $\begin{array}{l}\text { Annual } \\
\text { births in } \\
2016 / 17 \ddagger\end{array}$ \\
\hline & $A$ & B & & $A+B$ & $(A+B) / 2 D$ & $B / 2 D$ & c & $C / 2 E \times 1000$ & $D$ & $E$ \\
\hline Colombia & 100255 & 9717 & 91 & 109972 & 1.13 & 0.099 & 248 & 0.190 & 48860 & 652112 \\
\hline Guatemala & 4003 & 1054 & 79 & 5057 & 0.15 & 0.031 & 140 & 0.181 & 16793 & 386023 \\
\hline $\begin{array}{l}\text { Dominican } \\
\text { Republic }\end{array}$ & 5248 & 336 & 93 & 5584 & 0.26 & 0.015 & 85 & 0.296 & 10708 & 143822 \\
\hline Puerto Rico & - & 36871 & 0 & 36871 & 10.02 & 10.016 & 47 & 0.892 & 1840 & 26357 \\
\hline $\begin{array}{l}\text { Trinidad and } \\
\text { Tobago }\end{array}$ & - & 722 & 0 & 722 & 0.26 & 0.264 & 17 & 0.475 & 1367 & 17883 \\
\hline Ecuador & 3722 & 3011 & 55 & 6733 & 0.20 & 0.091 & 14 & 0.025 & 16505 & 283020 \\
\hline Bolivia & 2216 & 816 & 73 & 3032 & 0.14 & 0.037 & 14 & 0.027 & 10970 & 255713 \\
\hline Honduras & 31378 & 266 & 99 & 31644 & 1.81 & 0.015 & 8 & 0.022 & 8727 & 184312 \\
\hline Martinique & 37997 & - & 100 & 37997 & 48.65 & 0.000 & 5 & 0.674 & 390 & 3711 \\
\hline Guadeloupe & 32250 & 28 & 99 & 32278 & 35.05 & 0.030 & 5 & 0.570 & 460 & 4389 \\
\hline Argentina & 536 & 276 & 66 & 812 & 0.01 & 0.003 & 5 & 0.003 & 44059 & 716322 \\
\hline El Salvador & 12467 & 3 & 99 & 12470 & 1.00 & 0.000 & 4 & 0.018 & 6262 & 109617 \\
\hline Suriname & 2816 & 733 & 79 & 3549 & 3.19 & 0.659 & 4 & 0.203 & 555 & 9847 \\
\hline Saint Martin & 1580 & 200 & 88 & 1780 & 55.63 & 6.250 & 1 & 1.000 & 16 & 500 \\
\hline Barbados & 672 & 137 & 83 & 809 & 1.39 & 0.234 & 1 & 0.196 & 291 & 2552 \\
\hline Venezuela & 61708 & - & 100 & 61708 & 0.97 & 0.000 & 0 & 0 & 31748 & 602123 \\
\hline Jamaica & 6958 & 186 & 97 & 7144 & 1.25 & 0.032 & 0 & 0 & 2846 & 35164 \\
\hline Peru & 5737 & 1293 & 81 & 7030 & 0.11 & 0.020 & 0 & 0 & 31969 & 502591 \\
\hline Curacao & 4362 & 2020 & 68 & 6382 & 21.27 & 6.733 & 0 & 0 & 150 & 1668 \\
\hline Belize & 1762 & 269 & 86 & 2031 & 2.74 & 0.362 & 0 & 0 & 371 & 7200 \\
\hline Cuba & 1305 & 324 & 80 & 1629 & 0.07 & 0.014 & 0 & 0 & 11439 & 115921 \\
\hline Aruba & 830 & 645 & 56 & 1475 & 6.44 & 2.816 & 0 & 0 & 114 & 1230 \\
\hline Dominica & 1154 & 79 & 93 & 1233 & 8.33 & 0.533 & 0 & 0 & 74 & 721 \\
\hline $\begin{array}{l}\text { Saint Vincent } \\
\text { and the } \\
\text { Grenadines }\end{array}$ & 505 & 84 & 85 & 589 & 5.77 & 0.823 & 0 & 0 & 51 & 1634 \\
\hline $\begin{array}{l}\text { Saint Kitts and } \\
\text { Nevis }\end{array}$ & 554 & 33 & 94 & 587 & 5.59 & 0.314 & 0 & 0 & 52 & 641 \\
\hline $\begin{array}{l}\text { Antigua and } \\
\text { Barbuda }\end{array}$ & 537 & 25 & 95 & 562 & 2.97 & 0.132 & 0 & 0 & 94 & 1085 \\
\hline Bahamas & 510 & 25 & 95 & 535 & 0.68 & 0.031 & 0 & 0 & 394 & 4055 \\
\hline
\end{tabular}

Continued 
Table 1 Continued

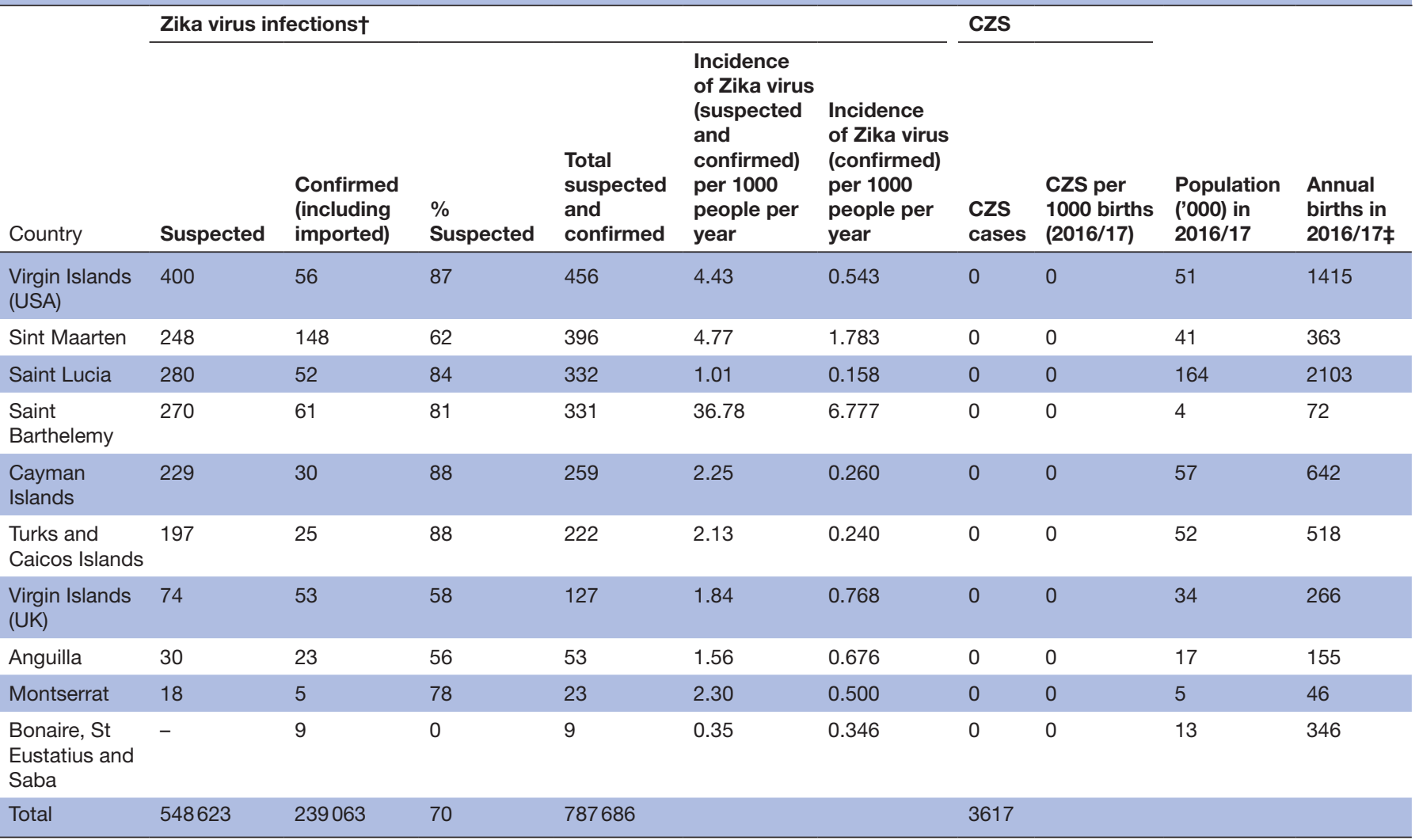

1. Brazil Ministry of Health case definition for confirmed cases of congenital syndrome associated with Zika virus infection includes confirmed and probable cases per PAHO's case definition.

2. The number of confirmed congenital syndrome associated with Zika include two autochthonous cases and three imported cases.

3. The reported number of suspected cases of Zika virus infection are estimates. According to Santé publique France, the estimated number of suspected cases is the sum of the number of visits recorded by the Decentralised Centres of Prevention and Care and the estimated number of people who sought medical care from a general practitioner for this purpose. The estimate is based on data collected by the sentinel physician network.

4. The case reported by Santé publique France corresponds to a fetus with cerebral malformation of a mother infected with Zika.

5 . In addition to the five reported cases of congenital syndrome, Santé publique France reported 16 fetuses with cerebral malformations of mothers infected with

Zika.

6. Santé publique France reported 21 fetuses with cerebral malformations of mothers infected with Zika.

7. In addition to the one reported case of congenital syndrome, Santé publique France reported 18 fetuses with cerebral malformations of mothers infected with

Zika.

${ }^{*}$ CZS cases in Brazil occurring in 2015 are included.

†PAHO/WHO case definitions for suspected and confirmed Zika virus infections is available at: http://www.paho.org/hq/index.php?option=com content\&view=article\&id=11117\&ltemid=41532\&lang=en.

¥Total births were estimated as twice the most recent birth years if data were not available for 2016 and 2017: Honduras (2012), Haiti (2013), Grenada (2014), Trinidad and Tobago (2015), El Salvador (2015) and Guyana (2015).

§Confirmed congenital syndrome associated with Zika virus infection case definition: live newborn who meets the criteria for a suspected case of congenital syndrome associated with Zika virus and Zika virus infection was detected in specimens of the newborn, regardless of detection of other pathogens. Case definitions for congenital syndrome associated with Zika virus infection is available at: http://www.paho.org/hq/index.php?option=com content\&view=article\&id=11117\&ltemid=41532\&lang=en.

CZS, congenital Zika syndrome; PAHO, Pan American Health Organization.

\section{DISCUSSION}

This study is the first comprehensive study in the Americas of the entire course of the Zika epidemic using the infectious disease surveillance reports together with the number of population births. The study demonstrates again that the vast majority of CZS cases occurred in Brazil. In Brazil, 2952 CZS cases were reported, compared with a baseline of about 380 cases of microcephaly expected over that 2-year period. ${ }^{16}$ The study has shown in addition a high epidemic intensity in some of the Caribbean islands. The phenomenon of a very high proportion of individuals on an island being infected has been noted for both Zika virus and other infections.
Kucharski et alstudied the outbreak of ZIKV from 2013 to 2014 in French Polynesia and concluded that $94 \%$ of the population were infected during the outbreak. ${ }^{13}$ The first reported epidemic of Zika virus in the island of Yap in $2007^{17}$ reported over $70 \%$ of residents had been infected. Dengue shows a similar pattern of high infection rates on islands, and this also results in a more cyclical pattern of population infection every 12-15 years compared with the lower and more constant dengue virus infection rates in larger communities. ${ }^{18}$

Susceptibility to Zika virus infection varies hugely according to climatic, environmental and social factors. How, it would be expected that the risk of an infected 


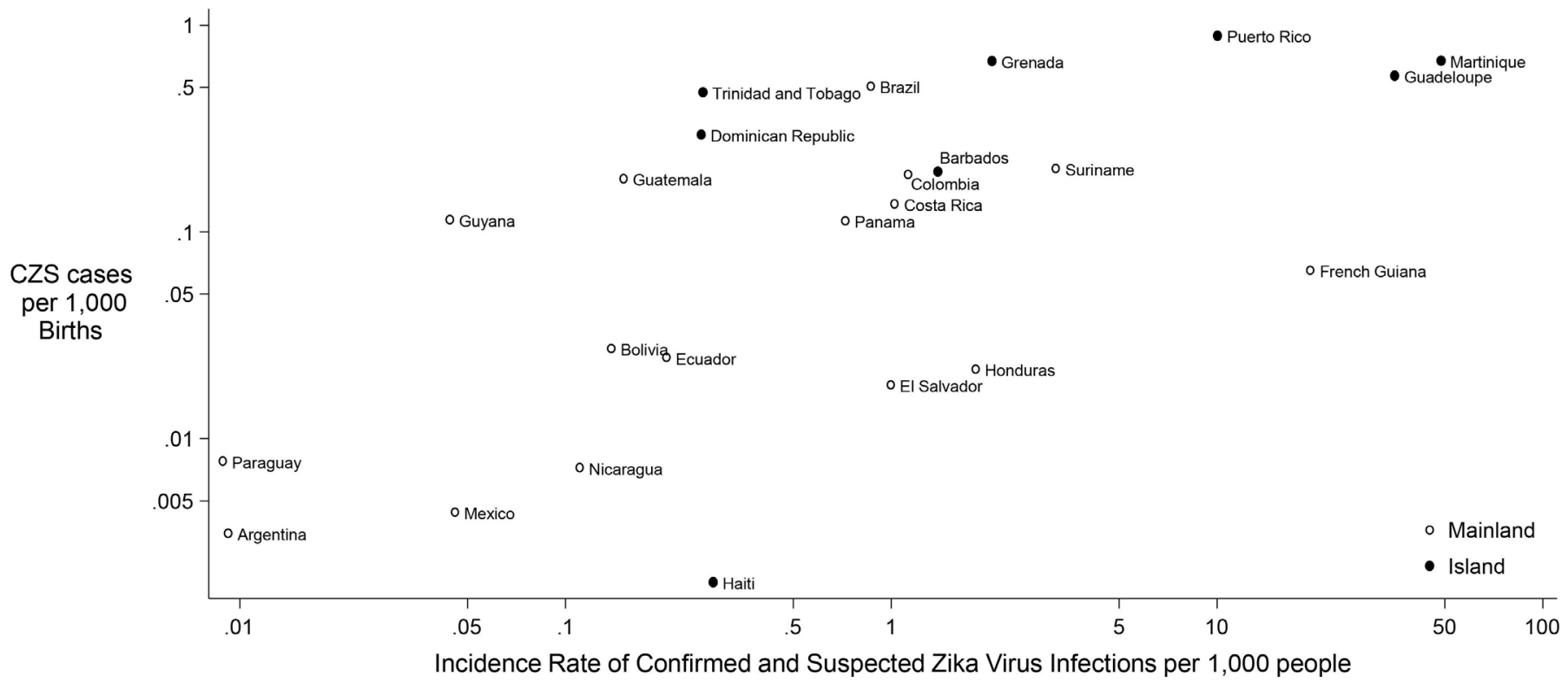

Figure 1 Congenital Zika syndrome (CZS) cases per 1000 births compared with the incidence of Zika virus infections.

pregnancy resulting in CZS is likely to have a much small variation. The occurrence of discordant twins for CZS shows that ZIKV infection during pregnancy is not deterministic for CZS phenotype and that other susceptibility factors might be involved. ${ }^{19}$ Comparing the calculated number of CZS cases per 1000 infected pregnent woman with the expected 4-60 CZS case per 1000 infected pregnant women, reveals the huge variations in testing and reporting of Zika virus infections in Latin America. Interpretation of infectious disease reports should therefore be cautious. Although we found a clumping of countries around the expected 4-60 CZS per 1000 infected pregnant women, the infectious disease reports are clearly not suitable for such estimations which must come from properly designed epidemiological studies such as cohort studies. However, the potential imbalance due to susceptibility factors is likely to be of a much smaller order of magnitude than the occurrence of under-reporting indicated in this study.

A comparison between Brazil, Colombia and Puerto Rico is instructive to understand the complexity of comparing CZS figures between countries. The incidence of confirmed plus suspected Zika virus cases per 1000 people varied $>10$-fold from 0.86 in Colombia, 1.12 in Brazil to 10 in Puerto Rico, while in contrast the prevalence of CZS per 1000 births varied <5-fold from 0.19 in Colombia, to 0.51 in Brazil and 0.89 in Puerto Rico. In Colombia, termination of pregnancy was allowed in cases with $\mathrm{CZS},{ }^{20}$ thereby potentially decreasing the birth prevalence of CZS in Colombia relative to the infection rate. Brazil used a lower threshold for diagnosing microcephaly and hence CZS at the beginning of the epidemic which may have inflated the earlier reports relative to other countries. All three countries were more likely to test and report Zika virus infections in pregnant women than in the general population. Calculating the number of CZS births per 1000 births to women infected with
Zika virus (suspected or confirmed) results in values of 12 in Colombia, 113 in Brazil and 12 in Puerto Rico. In addition to Brazil using a lower threshold for diagnosing microcephaly, at the start of the epidemic in Brazil pregnant women were not tested for Zika virus infection, but only judged to have been infected once the child was diagnosed with CZS, both of which would cause the number of CZS cases per infected pregnant women to be much higher. However, there may also be some underreporting of CZS in Colombia and Puerto Rico compared with Brazil.

There are many factors influencing the reporting of both Zika virus and CZS. For Zika virus, reporting depends on the true rate of infection in the population, the proportion of symptomatic people with access to healthcare presenting at health centres, the policy as to which suspected infections should have laboratory confirmation (eg, in Brazil testing was restricted mainly to pregnant women), the difficulties of retrospective confirmation of infection as it is difficult to distinguish Zika from other flaviviruses outside the viraemic phase, and the exhaustiveness of public health reporting mechanisms.

For CZS, reporting also depends on the proportion of affected babies/mothers with clinical signs of CZS tested for Zika virus, and the proportion of affected pregnancies who proceed to live birth. In addition to the above factors, and particularly the difficulty of confirming fetal Zika virus infection after birth, there are issues with the consistency of diagnoses of microcephaly, and with the reporting of terminations of pregnancy where they are legal. Inconsistencies in microcephaly diagnosis have been identified across European, US and South American congenital anomaly registries prior to the Zika epidemic. $^{102122}$ In March 2016, WHO issued new guidance as to the diagnoses of microcephaly 'Neonates with a head circumference $>2$ SD below the mean are considered to have microcephaly. Neonates with a head 
Table 2 Zika virus infections in pregnant women in countries in the South and Central Americas, Mexico and the Caribbean, 2015-2017 and the number of CZS cases per 1000 pregnant women with Zika virus and number of pregnant women with Zika virus per 1000 births

\begin{tabular}{|c|c|c|c|c|c|c|}
\hline \multirow[b]{2}{*}{ Country } & \multirow[b]{2}{*}{$\begin{array}{l}\text { CZS cases } \\
\text { (table 1) }\end{array}$} & \multicolumn{2}{|c|}{$\begin{array}{l}\text { Reported number of } \\
\text { pregnant women with Zika } \\
\text { virus }\end{array}$} & \multirow{2}{*}{$\begin{array}{l}\text { Date } \\
\text { pregnancies } \\
\text { reported (week/ } \\
\text { year) }\end{array}$} & \multirow{2}{*}{$\begin{array}{l}\text { CZS cases per } \\
1000 \text { pregnant } \\
\text { women with Zika } \\
\text { virus suspected } \\
\text { or confirmed }\end{array}$} & \multirow{2}{*}{$\begin{array}{l}\text { Number of pregnan } \\
\text { women with Zika } \\
\text { virus suspected or } \\
\text { confirmed per } 1000 \\
\text { births* }^{*}\end{array}$} \\
\hline & & $\begin{array}{l}\text { Zika virus } \\
\text { suspected or } \\
\text { confirmed }\end{array}$ & $\begin{array}{l}\text { Zika virus } \\
\text { confirmed }\end{array}$ & & & \\
\hline & c & G & $H$ & & $C / G \times 1000$ & G/E (table 1) $\times 1000$ \\
\hline Brazil & 2952 & 26066 & 11546 & $22 / 2017$ & 113.3 & 4.5 \\
\hline Colombia & 248 & 19993 & 6365 & $33 / 2017$ & 12.4 & 15.3 \\
\hline Guatemala & 140 & 1414 & 341 & $31 / 2017$ & 99.0 & 1.8 \\
\hline Dominican Republic & 85 & 966 & 271 & $30 / 2017$ & 88.0 & 3.4 \\
\hline Puerto Rico & 47 & NR & 4047 & $35 / 2017$ & 11.6 & 76.8 \\
\hline Mexico & 20 & NR & 5667 & $34 / 2017$ & 3.5 & 1.3 \\
\hline Costa Rica & 19 & NR & 210 & $33 / 2017$ & 90.5 & 1.5 \\
\hline Panama & 17 & 212 & 86 & $35 / 2017$ & 80.2 & 1.4 \\
\hline Trinidad and Tobago & 17 & NR & 463 & 8/2017† & 36.7 & 12.9 \\
\hline Ecuador & 14 & NR & 912 & $32 / 2017$ & 15.4 & 1.6 \\
\hline Bolivia & 14 & NR & 189 & $24 / 2017$ & 74.1 & 0.4 \\
\hline Honduras & 8 & 681 & 125 & $33 / 2017$ & 11.7 & 1.8 \\
\hline Martinique & 5 & NR & 830 & $30 / 2017$ & 6.0 & 111.8 \\
\hline Guadeloupe & 5 & NR & 815 & $30 / 2017$ & 6.1 & 92.8 \\
\hline Argentina & 5 & NR & 5 & $35 / 2017$ & 1000.0 & 0.003 \\
\hline EI Salvador & 4 & 391 & NR & $33 / 2017$ & 10.2 & 1.8 \\
\hline Suriname & 4 & NR & NR & $35 / 2017$ & & \\
\hline Guyana & 3 & NR & NR & $35 / 2017$ & & \\
\hline Nicaragua & 2 & NR & 1117 & 1/2017† & 1.8 & 4.1 \\
\hline Grenada & 2 & NR & NR & $22 / 2017$ & & \\
\hline Paraguay & 2 & 31 & 3 & $28 / 2017$ & 64.5 & 0.1 \\
\hline French Guiana & 1 & NR & 2211 & $36 / 2017$ & 0.5 & 144.3 \\
\hline Haiti & 1 & 22 & NR & 21/2016† & 45.5 & 0.04 \\
\hline Saint Martin & 1 & NR & 48 & $30 / 2017$ & 20.8 & 48.0 \\
\hline Barbados & 1 & NR & 32 & $32 / 2017$ & 31.3 & 6.3 \\
\hline Venezuela & 0 & 3463 & NR & $12 / 2017$ & 0 & 2.9 \\
\hline Jamaica & 0 & 712 & 78 & $12 / 2017$ & 0 & 10.1 \\
\hline Peru & 0 & NR & 279 & $33 / 2017$ & 0 & 0.3 \\
\hline Curacao & 0 & NR & 30 & 44/2016† & 0 & 9.0 \\
\hline Belize & 0 & NR & 1 & 20/2016† & 0 & 0.1 \\
\hline Cuba & 0 & NR & NR & $35 / 2017$ & & \\
\hline Aruba & 0 & NR & NR & $35 / 2017$ & & \\
\hline Dominica & 0 & 13 & 10 & 38/2016† & 0 & 9.0 \\
\hline $\begin{array}{l}\text { Saint Vincent and the } \\
\text { Grenadines }\end{array}$ & 0 & 3 & 1 & $35 / 2016 \dagger$ & 0 & 0.9 \\
\hline Saint Kitts and Nevis & 0 & NR & NR & $35 / 2017$ & & \\
\hline Antigua and Barbuda & 0 & 16 & 6 & $27 / 2017$ & 0 & 7.4 \\
\hline Bahamas & 0 & NR & NR & $35 / 2017$ & & \\
\hline Virgin Islands (USA) & 0 & NR & 286 & $34 / 2017$ & 0 & 101.1 \\
\hline
\end{tabular}

Continued 
Table 2 Continued

\begin{tabular}{|c|c|c|c|c|c|c|}
\hline \multirow[b]{2}{*}{ Country } & \multirow[b]{2}{*}{$\begin{array}{l}\text { CZS cases } \\
\text { (table 1) }\end{array}$} & \multicolumn{2}{|c|}{$\begin{array}{l}\text { Reported number of } \\
\text { pregnant women with Zika } \\
\text { virus }\end{array}$} & \multirow{2}{*}{$\begin{array}{l}\text { Date } \\
\text { pregnancies } \\
\text { reported (week/ } \\
\text { year) }\end{array}$} & \multirow{2}{*}{$\begin{array}{l}\text { CZS cases per } \\
1000 \text { pregnant } \\
\text { women with Zika } \\
\text { virus suspected } \\
\text { or confirmed* }\end{array}$} & \multirow{2}{*}{$\begin{array}{l}\text { Number of pregnant } \\
\text { women with Zika } \\
\text { virus suspected or } \\
\text { confirmed per } 1000 \\
\text { births* }\end{array}$} \\
\hline & & $\begin{array}{l}\text { Zika virus } \\
\text { suspected or } \\
\text { confirmed }\end{array}$ & $\begin{array}{l}\text { Zika virus } \\
\text { confirmed }\end{array}$ & & & \\
\hline Sint Maarten & 0 & 10 & 1 & $35 / 2017$ & 0 & 13.8 \\
\hline Saint Barthelemy & 0 & NR & 11 & $30 / 2017$ & 0 & 76.4 \\
\hline Cayman Islands & 0 & NR & NR & $35 / 2017$ & & \\
\hline $\begin{array}{l}\text { Turks and Caicos } \\
\text { Islands }\end{array}$ & 0 & NR & NR & $35 / 2017$ & & \\
\hline Virgin Islands (UK) & 0 & NR & NR & $35 / 2017$ & & \\
\hline Total & 3617 & 54077 & 36025 & & & \\
\hline
\end{tabular}

*Numbers of pregnancies suspected or confirmed used unless this is not reported. In this case, number of confirmed pregnancies is used. †Potentially incomplete data on infected pregnancies due to early reporting dates.

NR, not reported.

circumference $>3$ SD below the mean should be considered to have severe microcephaly'. (Assessment of infants with microcephaly in the context of Zika virus Interim guidance 4 March 2016 'WHO/ZIKV/MOC/16.3 Rev.1' http:// www.who.int/csr/resources/publications/zika/ assessment-infants/en/.) Many countries had been using

Zika virus infection in pregnancy compared with incidence of Zika virus in the population

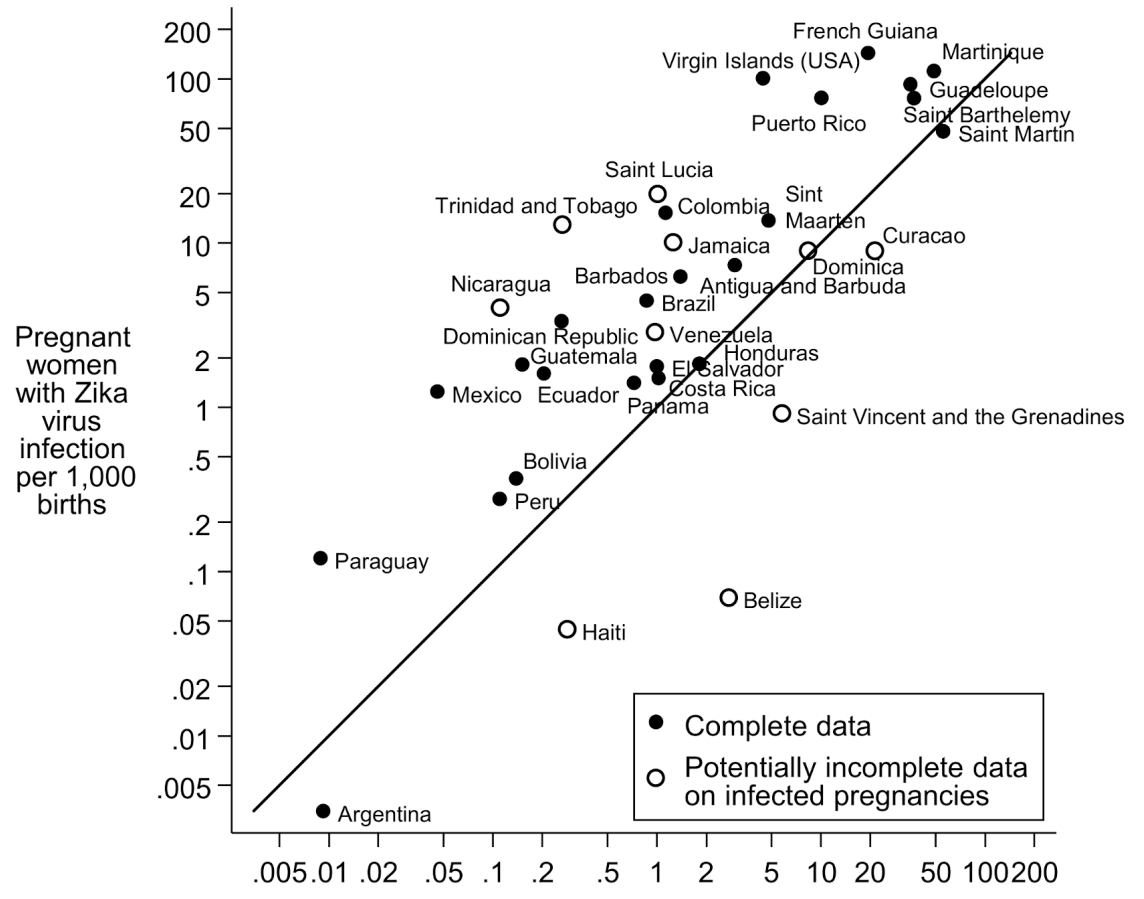

Figure 2 Number of congenital Zika syndrome (CZS) cases per 1000 infected pregnancies (95\% Cl). 


\section{Number of CZS cases per 1,000 infected pregnancies $(95 \% \mathrm{CI})$}

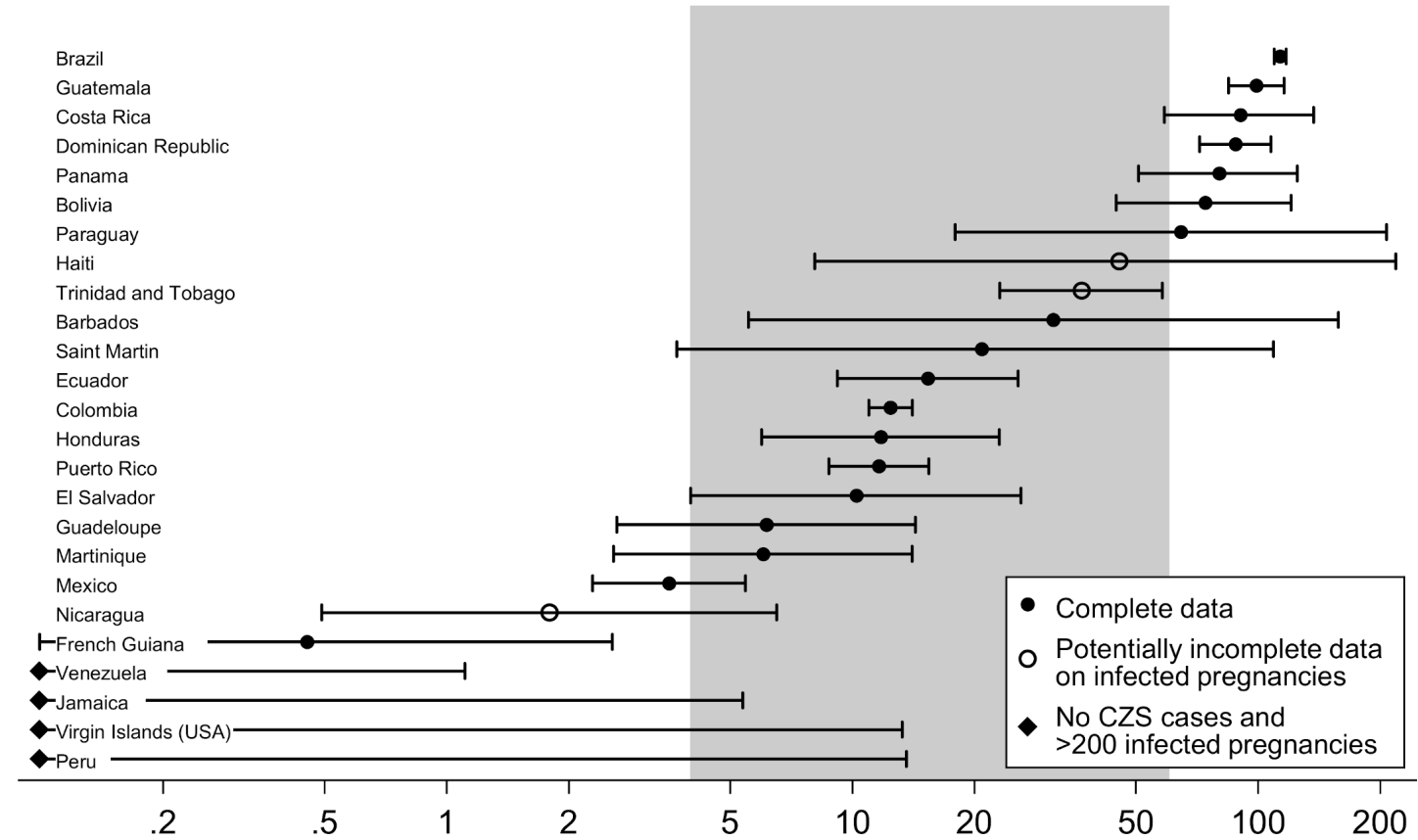

Figure 3 Zika virus infection in pregnancy compared with incidence of Zika virus in the population.

a definition of $>3 \mathrm{SD}$ below the mean for microcephaly. This change in definition was likely to have greatly increased the numbers of microcephaly diagnoses made. At the start of the CZS epidemic, many countries did not have the resources to diagnose cases as soon as they were born. ${ }^{23}$

Despite the evidence of under-reporting, other researchers have attempted to use these published figures to investigate the Zika virus epidemic. A study by Hay $e t$ $a l^{24}$ used the publicly available data from Brazil and Colombia to attempt to determine the gestational age risk of ZIKV infection and microcephaly. They concluded that the currently available surveillance data were insufficient to use in estimating risks of microcephaly from ZIKV infection.

Our analyses of CZS per 1000 births and the number of CZS per 1000 births to pregnant women with Zika virus provides considerable added value for estimating the burden of disease, including highlighting areas of data inconsistency, and we suggest this should be added to routine $\mathrm{PAHO}$ output, and to WHO output in general in tracking future epidemics. This will also make it easier to assess the impact of preventive interventions (eg, to prevent infection among pregnant women during an epidemic). Countries also need to report centrally how they ascertain cases of both Zika virus and CZS in order

Table 3 Comparison of cumulative numbers of CZS reported to PAHO/WHO and those predicted by Zhang et al in spread of Zika virus in Latin America and the Caribbean ${ }^{14}$

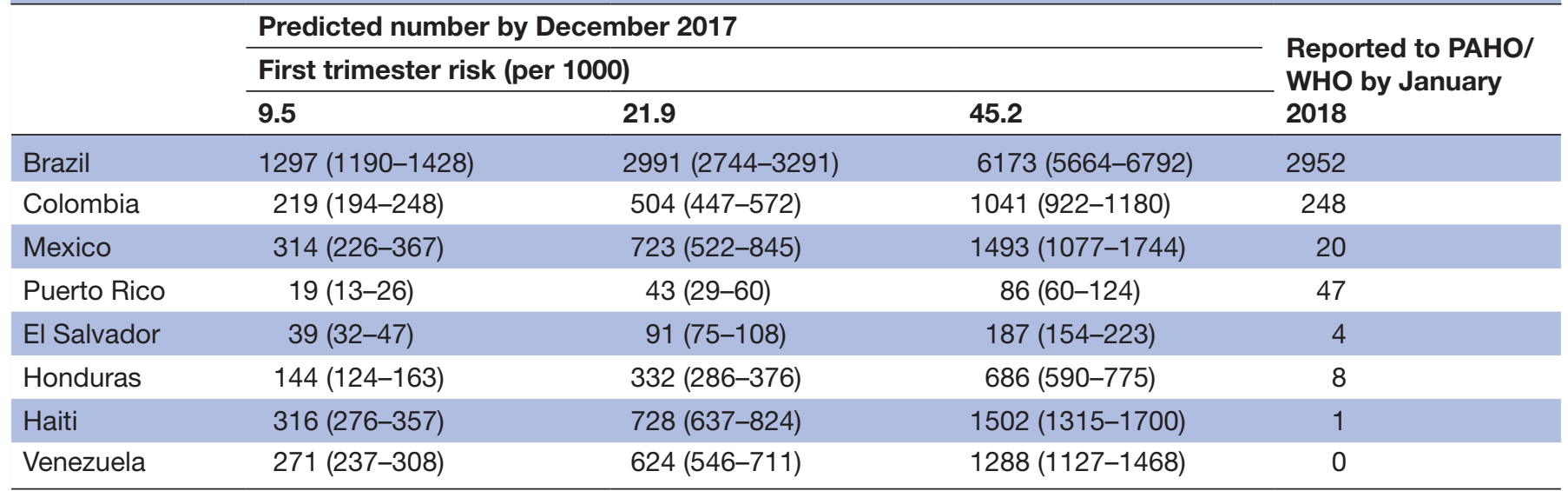

CZS, congenital Zika syndrome; PAHO, Pan American Health Organization. 
to help interpretation, as this information is currently not publicly available in a coordinated manner. These issues have recurred again in a different form in COVID-19 reporting, where WHO figures lack population denominators, and lack information about testing regimes in different countries, leading to potentially misleading interpretations of differences between countries.

CZS is likely to identify only those children severely affected and identifiable at birth. It is believed that many further thousands of children will suffer some effects despite appearing healthy at birth. These figures show the cost of the Zika virus epidemic across the South and Central Americas, Mexico and the Caribbean and highlight that many areas will need considerable resources to cope with the long-term effects in children.

\section{Patient and public involvement}

Patients or the public were not involved in the design, or conduct, or reporting, or dissemination plans of our research.

\section{Author affiliations}

${ }^{1}$ Population Health Research Institute, St George's, University of London, London, UK ${ }^{2}$ Maternal Fetal and Infant Research Centre, Institute of Nursing and Health Research, Ulster University - Jordanstown Campus, Newtownabbey, UK

${ }^{3}$ Latin American Center of Perinatology, Women and Reproductive Health, Pan American Health Organization, Montevideo, Uruguay

${ }^{4}$ Latin American Network of Congenital Malformations (ReLAMC) at Department of Genetics, Federal University of Rio de Janeiro, Rio de Janeiro, Brazil

${ }^{5}$ National Institute of Science and Technology of Medical Genetics Population, Porto Alegre, Brazil

Contributors JKM designed the study, obtained the data, interpreted the data and drafted the manuscript. HD contributed to the study design, the interpretation of the data and the drafting of the manuscript. PD and IMO both reviewed the manuscript and offered important suggestions for its revision.

Funding This project, ZikaPLAN is funded by the European Union's Horizon 2020 research and innovation programme under Grant Agreement №. 734584.

Competing interests None declared.

Patient and public involvement Patients and/or the public were not involved in the design, or conduct, or reporting, or dissemination plans of this research.

Patient consent for publication Not required.

Provenance and peer review Not commissioned; externally peer reviewed.

Data availability statement All data relevant to the study are included in the article. All data analysed in this paper are listed in Table 1 and Table 2.

Open access This is an open access article distributed in accordance with the Creative Commons Attribution Non Commercial (CC BY-NC 4.0) license, which permits others to distribute, remix, adapt, build upon this work non-commercially, and license their derivative works on different terms, provided the original work is properly cited, appropriate credit is given, any changes made indicated, and the use is non-commercial. See: http://creativecommons.org/licenses/by-nc/4.0/.

ORCID iD

Joan K Morris http://orcid.org/0000-0002-7164-612X
REFERENCES

1 Schuler-Faccini L, Ribeiro EM, Feitosa IML, et al. Possible association between Zika virus infection and microcephaly - Brazil, 2015. MMWR Morb Mortal Wkly Rep 2016;65:59-62.

2 Rasmussen SA, Jamieson DJ, Honein MA, et al. Zika virus and birth defects - reviewing the evidence for causality. $N$ Engl $\mathrm{J}$ Med 2016;374:1981-7.

3 Honein MA, Dawson AL, Petersen EE, et al. Birth defects among fetuses and infants of US women with evidence of possible Zika virus infection during pregnancy. JAMA 2017;317:59-68.

4 Moore CA, Staples JE, Dobyns WB, et al. Characterizing the pattern of anomalies in congenital zika syndrome for pediatric clinicians. JAMA Pediatr 2017;171:288-95.

5 Miranda-Filho DdeB, Martelli CMT, Ximenes RAdeA, et al. Initial description of the presumed congenital Zika syndrome. Am J Public Health 2016;106:598-600.

6 de Araújo TVB, Ximenes RAdeA, Miranda-Filho DdeB, et al. Association between microcephaly, Zika virus infection, and other risk factors in Brazil: final report of a case-control study. Lancet Infect Dis 2018;18:328-36.

7 Cauchemez S, Besnard M, Bompard P, et al. Association between Zika virus and microcephaly in French Polynesia, 2013-15: a retrospective study. Lancet 2016;387:2125-32.

8 Brady OJ, Osgood-Zimmerman A, Kassebaum NJ, et al. The association between Zika virus infection and microcephaly in Brazil 2015-2017: an observational analysis of over 4 million births. PLoS Med 2019;16:e1002755.

9 Brasil P, Pereira JP, Moreira ME, et al. Zika virus infection in pregnant women in Rio de Janeiro. N Engl J Med 2016;375:2321-34.

10 Orioli IM, Dolk H, Lopez-Camelo JS, et al. Prevalence and clinical profile of microcephaly in South America pre-Zika, 2005-14: prevalence and case-control study. BMJ 2017;359:j5018.

$11 \mathrm{PAHO}, \mathrm{WHO}$, Zika suspected and confirmed cases reported by countries and territories in the Americas. Cummulative cases 2015 2016, 2016.

12 United Nations. United nations demographic yearbook 2017, 2019.

13 Kucharski AJ, Funk S, Eggo RM, et al. Transmission dynamics of Zika virus in island populations: a modelling analysis of the 2013-14 French Polynesia outbreak. PLoS Negl Trop Dis 2016;10:e0004726.

14 Zhang Qet al. Spread of Zika virus in the Americas. Proceedings of the national academy of sciences, 2017.

15 Johansson MAet al. Zika and the risk of microcephaly. [Erratum appears in N Engl J Med. 2016, 375(5):498; PMID: 27518688]. N Engl J Med 2016;375:1-4.

16 Marinho F, Araújo VEMde, Porto DL, et al. Microcephaly in Brazil: prevalence and characterization of cases from the information system on live births (Sinasc), 2000-2015. Epidemiol Serv Saude 2016;25:701-12.

17 Duffy MR, Chen T-H, Hancock WT, et al. Zika virus outbreak on YAP Island, Federated states of Micronesia. N Engl J Med 2009;360:2536-43.

18 Cao-Lormeau V-M, Roche C, Musso D, et al. Dengue virus type 3, South Pacific Islands, 2013. Emerg Infect Dis 2014;20:1034-6.

19 Caires-Júnior LC, Goulart E, Melo US, et al. Discordant congenital Zika syndrome twins show differential in vitro viral susceptibility of neural progenitor cells. Nat Commun 2018;9:475.

20 Carabali M, Austin N, King NB, et al. The Zika epidemic and abortion in Latin America: a scoping review. Glob Health Res Policy 2018;3:15.

21 Morris JK, Rankin J, Garne E, et al. Prevalence of microcephaly in Europe: population based study. BMJ 2016;354:i4721.

22 Cragan JD, Isenburg JL, Parker SE, et al. Population-based microcephaly surveillance in the United States, 2009 to 2013: an analysis of potential sources of variation. Birth Defects Res A Clin Mol Teratol 2016;106:972-82.

23 Alvarado-Socarras JL, Idrovo Álvaro J, Contreras-García GA, et al. Congenital microcephaly: a diagnostic challenge during Zika epidemics. Travel Med Infect Dis 2018;23:14-20.

24 Hay JA, Nouvellet P, Donnelly CA, et al. Potential inconsistencies in Zika surveillance data and our understanding of risk during pregnancy. PLoS Negl Trop Dis 2018;12:e0006991. 